\title{
Asfiksia Neonatorum Sebagai Faktor Risiko Gagal Ginjal Akut
}

\author{
Adhie Nur Radityo, M Sholeh Kosim, Heru Muryawan \\ Bagian Ilmu Kesehatan Anak Fakultas Kedokteran Universitas Diponegoro/RSUP Dr. Kariadi, Semarang
}

Latar belakang. Asfiksia merupakan salah satu penyebab mortalitas dan morbiditas bayi baru lahir yang dapat berakibat kerusakan organ. Sekitar $50 \%$ kerusakan organ terjadi pada ginjal yang berakibat gagal ginjal akut (GGA). Diagnosis dan pengenalan GGA merupakan hal penting agar fungsi ginjal tetap terjaga.

Tujuan. Membuktikan asfiksia merupakan faktor risiko terjadinya GGA.

Metode. Penelitian kohort prospektif dengan subyek sesuai kriteria inklusi bayi baru lahir dengan asfiksia di RSUP Dr. Kariadi Semarang bulan Januari-Desember 2010. Sebagai kelompok terpapar adalah neonatus asfiksia berat dan neonatus asfiksia sedang sebagai kelompok tidak terpapar. Subyek dipilih secara consecutive sampling. Diagnosis GGA berdasarkan kadar ureum, kreatinin dan pengukuran diuresis pada hari keempat dan kelima perawatan. Analisis dengan uji Chi-square, Mann-Whitney, Kolmogorov-Smirnov dan t tidak berpasangan.

Hasil. Subjek 63 neonatus., kejadian GGA pada neonatus asfiksia sedang dan berat 39,7\%, keseluruhan kasus GGA merupakan tipe oliguria. Neonatus dengan GGA pada hari keempat rerata kadar ureum 33,6 $( \pm 13,53) \mathrm{mg} / \mathrm{dL}$, kreatinin $1,54( \pm 0,35) \mathrm{mg} / \mathrm{dL}$ dan diuresis $0,45( \pm 0,07) \mathrm{mL} / \mathrm{kgBB} / \mathrm{jam}$ dibandingkan rerata pada hari kelima terdapat peningkatan kadar ureum 41,36 $( \pm 14) \mathrm{mg} / \mathrm{dL}$, penurunan kadar kreatinin 1,39 $( \pm 0,3) \mathrm{mg} / \mathrm{dL}$, dan rerata diuresis $0,45( \pm 0,06) \mathrm{mL} / \mathrm{kgBB} / \mathrm{jam}(\mathrm{p}<0,05)$. Insidens GGA terbanyak terjadi pada asfiksia berat 56,3\% ( $\mathrm{p}=0,006$; RR 2,5; 95\% CI 1,2-5,1). Obat nefrotoksik bukan faktor risiko terjadinya gagal ginjal akut ( $\mathrm{p}=0,002$; RR 5,08; 95\%CI 0,77-33,66).

Kesimpulan. Asfiksia berat merupakan faktor risiko terjadinya GGA. Sari Pediatri 2012;13(5):305-10.

Kata kunci: gagal ginjal akut, asfiksia

\footnotetext{
Alamat korespondensi:

Dr. Adhie Nur Radityo. Bagian Ilmu Kesehatan Anak Fakultas Kedokteran UNDIP/RSUP Dr. Kariadi, Jl. Dr. Sutomo 16 - 18, Semarang. E-mail: dokter_adhie7@yahoo.com
}

$\begin{aligned} & \text { sfiksia merupakan salah satu penyebab } \\ & \text { mortalitas dan morbiditas bayi baru lahir } \\ & \text { dan akan membawa berbagai dampak pada } \\ & \text { periode neonatal. Menurut National Center }\end{aligned}$
for Health Statistics (NCHS) pada tahun 2002, asfiksia
neonatorum mengakibatkan 14 kematian per 100.000
kelahiran hidup di Amerika Serikat. ${ }^{1}$ Di RS Dr Kariadi
Semarang selama tahun 2007, angka kelahiran bayi 
hidup mencapai 1600 jiwa setahun dengan angka kejadian bayi lahir dengan asfiksia berjumlah 187 kelahiran. ${ }^{2}$ Asfiksia akan menyebabkan hipoksia dan iskemia pada bayi, mengrakibatkan kerusakan, sebagian besar terjadi pada ginjal (50\%), syaraf pusat (28\%), sistem kardiovaskular (25\%) dan paru (23\%). ${ }^{3}$ Ginjal merupakan organ yang paling sensitif terhadap keadaan penurunan kadar oksigen. Insufisiensi ginjal dapat terjadi pada duapuluh empat jam setelah keadaan hipoksia dan iskemia. Jika hipoksia ini tidak diatasi maka akan menimbulkan nekrosis korteks ginjal yang bersifat ireversibel. ${ }^{4}$

Gagal ginjal akut (GGA) adalah penurunan mendadak kecepatan filtrasi glomerulus (KFG) dengan ketidakmampuan mengeluarkan bahan terlarut dan air, yang mengakibatkan penimbunan bahan terlarut dan air. ${ }^{4,5,6}$ Kejadian GGA neonatus saat ini cenderung meningkat dan fungsi ginjal pada 35\%-71\% kasus GGA tidak dapat kembali sempurna. Bahkan angka kematian neonatus akibat GGA masih tinggi, yaitu antara 36\%-78\%..$^{5-8}$ Pengenalan keadaan kegagalan fungsi ginjal pada bayi asfiksia merupakan hal yang penting untuk melakukan pemberian cairan dan elektrolit agar didapatkan keseimbangan biokimia sehingga fungsi vitalnya dapat terjaga. ${ }^{8}$

Tujuan penelitian untuk membuktikan bahwa asfiksia neonatorum merupakan faktor risiko terjadinya gagal ginjal akut pada neonatus.

\section{Metode}

Penelitian kohort prospektif yang dilakukan di bangsal perawatan bayi risiko tinggi (PBRT) dan neonatal intensive care unit (NICU) Bagian Ilmu Kesehatan Anak FK Undip/RSUP dr. Kariadi Semarang, pada Januari 2010 sampai dengan Desember 2010. Subyek penelitian adalah bayi baru lahir yang mengalami asfiskia dengan kehamilan cukup bulan, berat lahir sesuai masa kehamilan, tidak menderita kelainan kongenital, sudah dijumpai diuresis yang cukup dalam 24 jam pertama, dan orang tua bersedia mengisi formulir persetujuan. Kriteria asfiksia ditentukan dengan nilai APGAR pada menit pertama 6-7 (asfiksia ringan), 4-5 (asfiksia sedang), 0-3 (asfiksia berat) disertai dengan hasil analisis gas darah, diambil segera setelah persalinan sebelum mendapat oksigen dan cairan paling lama 30 menit setelah lahir, $\mathrm{pH}<7,3$ dengan base excess (BE) $-9 \pm 4$.
Penilaian GGA berdasarkan hasil pemeriksaan kadar ureum dan kreatinin darah dalam dua kali pengukuran selang 24 jam, serta penurunan produksi urin sampai anuria. Disebut GGA apabila kadar ureum $>20 \mathrm{mg} / \mathrm{dL}$, kreatinin $>1 \mathrm{mg} / \mathrm{dL}$ dan produksi urin $<0,5-1 \mathrm{~mL} / \mathrm{kg}$ berat badan/jam (pengukuran dalam 6 jam) atau $<1 \mathrm{~mL} / \mathrm{kg}$ berat badan/hari.

Pemakaian obat nefrotoksik golongan aminoglikosida yaitu gentamisin diikutkan dalam analisis hasil sebagai variabel pengganggu yang menjadi faktor risiko tGGA. Pemberian obat nefrotoksik jika gentamisin diberikan dengan dosis $5 \mathrm{mg} / \mathrm{kg}$ berat badan/hari terbagi dua dosis selama minimal lima hari.

Data dianalisis dengan uji Chi-square. Besar pengaruh dinyatakan dengan besaran risiko yaitu risiko relatif (RR) untuk analisis bivariat dengan tingkat kemaknaan $\mathrm{p} \leq 0,05$ dengan 95\% interval kepercayaan. Analisis data dilakukan dengan program SPSS for Windows ver. 15,0.

\section{Hasil}

Selama periode Januari 2010 sampai dengan Desember 2010 didapatkan 77 neonatus yang memenuhi kriteria inklusi, 7 orang tua/wali menolak mengikuti penelitian dan 7 neonatus meninggal selama pemantauan. Total subyek penelitian adalah 63 neonatus dengan keadaan asfiksia, terdiri atas 31 neonatus asfiksia sedang dan 32 neonatus asfiksia berat. Karakteristik neonatus tertera pada Tabel 1 .

Tabel 1 memperlihatkan perbedaan distribusi berat badan antara kelompok asfiksia sedang dan berat. Neonatus asfiksia berat mempunyai kadar $\mathrm{pH}$ dan base excess yang lebih rendah secara bermakna dibanding asfiksia sedang. Kadar kreatinin dan rerata diuresis hari keempat dan kelima pada neonatus asfiksia berat, berbeda bermakna dengan asfiksia sedang.

Di antara 63 neonatus dengan asfiksia didapatkan bahwa 25 neonatus (39,7\%) mengalami gagal ginjal akut terdiri dari 18 neonatus asfiksia berat dan 7 neonatus asfiksia sedang (Tabel 2). Keseluruhan neonatus yang mengalami GGA merupakan tipe oliguria. Dari perhitungan statistik didapatkan bahwa asfiksia berat merupakan faktor risiko terjadi gagal ginjal akut, neonatus dengan asfiksia berat mempunyai kemungkinan 2,5 kali lebih besar terjadi gagal ginjal akut dibandingkan dengan neonatus 
asfiksia sedang (Tabel 2). Sebagian besar neonatus $(82,5 \%)$ mendapat gentamisin selama perawatan di bangsal. Hanya 24 neonatus (46\%) yang diberikan gentamisin mempunyai keluaran terjadi gagal ginjal akut (Tabel 3). Penggunaan obat gentamisin dengan dosis $5 \mathrm{mg} / \mathrm{kgBB} /$ hari terbagi dua dosis selama minimal lima hari bukan merupakan faktor risiko terhadap terjadinya gagal ginjal akut karena nilai 95\% interval kepercayaan melingkupi angka satu (Tabel 3).

Tabel 1. Karakteristik neonatus

\begin{tabular}{|c|c|c|c|}
\hline Karakteristik neonatus & $\begin{array}{c}\text { Asfiksia berat } \\
\mathrm{n}=32\end{array}$ & $\begin{array}{l}\text { Afiksia sedang } \\
\quad \mathrm{n}=31\end{array}$ & $p$ \\
\hline Berat lahir (gram) & $2.871,9 \pm 353,77$ & $3.060 \pm 353,9$ & $0,03^{*}$ \\
\hline \multicolumn{4}{|l|}{ Jenis kelamin bayi, n (\%) } \\
\hline - Laki-laki & $17(53)$ & $12(39)$ & \\
\hline - Perempuan & $15(47)$ & $19(61)$ & $0,2^{£}$ \\
\hline \multicolumn{4}{|l|}{ Cara lahir, n (\%) } \\
\hline - Spontan & $16(50)$ & $8(25,8)$ & \\
\hline - Sectio caesaria & $12(37,5)$ & $12(38,7)$ & \\
\hline - Ekstraksi vakum & $4(12,5)$ & $11(35,5)$ & $0,3^{¥}$ \\
\hline \multicolumn{4}{|l|}{ Analisis gas darah } \\
\hline - $\mathrm{pH}$ & $7,18 \pm 0,1$ & $7,23 \pm 0,5$ & $0,03^{*}$ \\
\hline - $\mathrm{pO} 2(\mathrm{mmHg})$ & $177,22 \pm 77,14$ & $181,94 \pm 70,61$ & $0,8^{\S}$ \\
\hline - $\mathrm{pCO} 2$ & $26,84 \pm 9,73$ & $24,68 \pm 6,38$ & $0,3^{\S}$ \\
\hline - Base excess $(\mathrm{mmol} / \mathrm{L})$ & $-14,96 \pm 4,39$ & $-12,74 \pm 3,52$ & $0,04^{*}$ \\
\hline \multicolumn{4}{|l|}{ Kadar ureum (mg/dl) } \\
\hline - Hari ke 4 & $27,19 \pm 14,01$ & $26,55 \pm 10,35$ & $0,6^{*}$ \\
\hline - Hari ke 5 & $32,38 \pm 16,44$ & $27,06 \pm 11,88$ & $0,15^{\S}$ \\
\hline \multicolumn{4}{|l|}{ Kadar kreatinin $(\mathrm{mg} / \mathrm{dl})$} \\
\hline - Hari ke 4 & $1,14 \pm 0,52$ & $0,84 \pm 0,46$ & $0,02^{\S}$ \\
\hline - Hari ke 5 & $1,06 \pm 0,48$ & $0,77 \pm 0,34$ & $0,02^{*}$ \\
\hline \multicolumn{4}{|l|}{ Rerata diuresis (ml) } \\
\hline - Hari ke 4 & $0,95 \pm 0,66$ & $1,26 \pm 0,5$ & $0,03^{*}$ \\
\hline - Hari ke 5 & $0,95 \pm 0,65$ & $1,43 \pm 0,59$ & $0,003^{*}$ \\
\hline
\end{tabular}

* Uji Mann-Whitney $\quad{ }^{£}$ Uji Chi-square $\quad{ }^{¥}$ Uji Kolmogorov-Smirnov ${ }^{\S}$ Uji t-tidak berpasangan

Tabel 2. Hubungan antara asfiksia dengan kejadian gagal ginjal akut

\begin{tabular}{|c|c|c|c|c|}
\hline \multirow{2}{*}{ Kelompok } & \multicolumn{2}{|c|}{ Keluaran, n (\%) } & \multirow{2}{*}{ RR (95\% CI) } & \multirow{2}{*}{$p$} \\
\hline & Gagal ginjal (+) & Gagal ginjal (-) & & \\
\hline Asfiksia berat & $18(56,3)$ & $14(43,7)$ & $2,5(1,2 \mathrm{~s} / \mathrm{d} 5,1)$ & $0,006^{¥}$ \\
\hline Asfiksia sedang & $7(22,6)$ & $24(77,4)$ & & \\
\hline
\end{tabular}

Tabel 3. Faktor yang berpengaruh terhadap gagal ginjal akut

\begin{tabular}{lcccc}
\hline \multirow{2}{*}{ Obat gentamisin } & \multicolumn{2}{c}{ Keluaran $\mathrm{n}(\%)$} & RR $(95 \% \mathrm{CI})$ & $p$ \\
\cline { 2 - 3 } & Gagal ginjal $(+)$ & Gagal ginjal $(-)$ & & \\
\hline Ya & $24(96)$ & $28(73,7)$ & & \\
Tidak & $1(4)$ & $10(26,3)$ & $5,08(0,77-33,66)$ & $0,052^{*}$ \\
\hline
\end{tabular}

${ }^{¥}$ Uji Chi-square 


\section{Pembahasan}

Terdapat perbedaan berat badan lahir pada karakteristik subyek penelitian. Hal tersebut sesuai dengan penelitian Gupta $\mathrm{dkk}^{9}$ yang menggunakan metode case control pada bayi asfiksia dan bayi sehat. Perbedaan rerata berat badan lahir ini tidak mempengaruhi hasil pemeriksaan ureum dan kreatinin karena subjek penelitian adalah bayi cukup bulan dan ginjal secara anatomis dan fungsional sudah terbentuk sempurna saat kehamilan trimester kedua.

Kami mendapatkan kadar $\mathrm{pH}$ dan base excess yang berbeda antara kelompok asfiksia berat dan sedang. Rerata kadar $\mathrm{pH}$ dan base excess lebih rendah pada kelompok asfiksia berat. Hankins $\mathrm{dkk}^{10}$ dan Karlowicz $\mathrm{dkk}^{11}$ melaporkan kadar $\mathrm{pH}$ dan base excess yang tidak berbeda jauh dengan penelitian kami. Dikatakan bahwa parameter kadar $\mathrm{pH}$ dan base excess merupakan faktor prediktif gangguan fungsi organ pada neonatus salah satunya adalah ginjal.

Semakin berat derajat asfiksia akan tampak dari kadar $\mathrm{pH}$ dan base excess. Asfiksia berat mempunyai kadar $\mathrm{pH}$ dan base excess yang lebih rendah sehingga keadaan asidosis metabolik yang terjadi semakin berat. Keadaan asidosis metabolik yang berat mengakibatkan penurunan aliran darah ke ginjal yang berlanjut pada penurunan volume efektif darah di ginjal berakibat terjadi nekrosis tubuler dan menurunkan fungsi ginjal. ${ }^{12}$

Hasil pemeriksaan kadar ureum tidak bermakna antara dua kelompok penelitian sedangkan kadar kreatinin berbeda bermakna. Hal ini tidak sesuai dengan hasil penelitian Umboh ${ }^{13}$ yang mendapatkan perbedaan bermakna kadar ureum dan kreatinin pada bayi asfiksia ringan-sedang dan asfiksia berat. Perbedaan ini kemungkinan disebabkan karena perbedaan pada hari pengambilan sampel pemeriksaan kadar ureum dan kreatinin, penelitian Umboh mengambil sampel ureum dan kreatinin pada usia satu hari sehingga didapatkan rerata kadar ureum yang lebih tinggi (asfiksia ringan-sedang 31,0 7,9 mg/dL; asfiksia berat $41,3 \pm 5,1 \mathrm{mg} / \mathrm{dL}$ ) yang kemungkinan disebabkan masih adanya pengaruh ureum dari ibu.

Rerata diuresis pada kedua kelompok berbeda bermakna dan hal ini sesuai dengan hasil penelitian Karlowicz $\mathrm{dkk}^{11}$ yang mendapatkan perbedaan rerata diuresis pada bayi dengan asfiksia sedang dan berat. Kelompok asfiksia berat mempunyai rerata diuresis yang lebih sedikit dibandingkan kelompok asfiksia sedang, hal ini disebabkan karena derajat asfiksia berpengaruh terhadap menurunnya filtrasi glomerulus dan disfungsi dari tubulus yang dapat mengakibatkan kejadian oliguria sampai anuria.

Seluruh parameter penegakkan diagnosis gagal ginjal akut pada penelitian ini didapatkan hasil yang berbeda bermakna baik kadar ureum, kreatinin dan pengukuran diuresis antara bayi yang mengalami gagal ginjal akut dan tidak gagal ginjal akut. Hal ini sesuai dengan penelitian oleh Mortazavi $\mathrm{dkk}^{14}$ yang meneliti mengenai parameter pemeriksaan gagal ginjal akut pada neonatus dan memang didapatkan perbedaan bermakna kadar ureum, kreatinin dan pengukuran diuresis pada neonatus yang mengalami gagal ginjal akut. Hal ini sesuai dengan teori yang menyatakan adanya kerusakan tubular dan penurunan laju filtrasi glomerulus akan meningkatkan kadar ureum, kreatinin dan menurunkan volume diuresis.

Semua bayi yang mengalami gagal ginjal akut merupakan tipe oliguria di mana pengukuran diuresis pada hari keempat dan kelima didapatkan hasil $<0,5$ $-1 \mathrm{~mL} / \mathrm{kgBB} / \mathrm{jam}$. Hal ini sesuai dengan penelitian sebelumnya oleh Robert dkk ${ }^{15}$ (1990) semua bayi pada kelompok asfiksia yang mengalami gagal ginjal akut dari pengukuran diuresis didapatkan hasil oliguria. Perbedaan dari penelitian tersebut adalah pada hari pengukuran diuresis di mana Robert melakukan pengukuran diuresis pada hari pertama. Penelitian lain mendapatkan hasil yang berbeda di mana Gupta $\mathrm{dkk}^{9}$ dan Karlowicz dkk $^{11}$ masih mendapatkan adanya kelompok non oliguria pada bayi asfiksia yang mengalami gagal ginjal akut. Kemungkinan perbedaan ini dikarenakan asfiksia ringan masuk ke dalam perhitungan kelompok sampel bayi dengan asfiksia, di mana asfiksia ringan hanya mengalami kerusakan parenkim ginjal yang minimal sehingga tidak menurunkan produksi dari diuresis.

Hal-hal lain yang mempengaruhi produksi diuresis telah dieliminasi pada penelitian ini yaitu status hidrasi setiap neonatus sama karena tidak didapatkan adanya tanda-tanda dehidrasi secara klinis selama pemantauan penelitian. Sedangkan pemberian obat yang mempengaruhi produksi diuresis seperti aminofillin memang tidak diberikan selama penelitian karena pemberian aminofillin diindikasikan pada apneu of prematurity, sedangkan sampel penelitian ini adalah neonatus cukup bulan. Sedangkan aminoglikosida yang mempunyai potensi nefrotoksik dimasukkan dalam analisis penelitian. 
Penelitian ini didapatkan bahwa asfiksia berat merupakan faktor risiko terhadap terjadinya gagal ginjal akut, di mana neonatus dengan asfiksia berat mempunyai kemungkinan 2,5 kali lebih besar terjadi gagal ginjal akut dibandingkan dengan neonatus asfiksia sedang. Hal ini sesuai dengan penelitian $\mathrm{Umboh}^{13}$ terdapat hubungan antara derajat asfiksia dengan gagal ginjal akut yaitu makin berat derajat asfiksia akan mengakibatkan penurunan laju filtrasi glomerulus. Perbedaan dengan penelitian Umboh bahwa pada penelitian tersebut tidak dihitung besarnya faktor risiko dan penegakan gagal ginjal akut hanya berdasarkan pemeriksaan ureum dan kreatinin pada hari pertama dan tidak dilakukan pengukuran rerata diuresis.

Secara fisiologis suplai darah ke daerah juksta medular lebih banyak dibandingkan korteks, padahal volume korteks tiga kali lebih besar dibandingkan medula dan secara mikroskopis membran basal glomerolus bayi tipis dan belum berkembang sempurna. Kondisi yang tidak menguntungkan tersebut menyebabkan fungsi ginjal pada bayi lebih mudah terganggu terutama pada keadaan stress seperti akibat keadaan hipoksia yang dapat mempengaruhi proses metabolisme dan homeostasis. Makin berat keadaan hipoksia akan makin meningkatkan risiko terjadinya kerusakan anatomis dan gangguan fisiologis pada ginjal. Gangguan fungsi ginjal pada tahap dini bersifat ringan dengan gejala azotemia prerenal yaitu kenaikan kadar kreatinin dan ureum serum akibat hipoperfusi di daerah korteks. Tahap selanjutnya gangguan bersifat sedang yang disebabkan hipoperfusi di daerah medula. Jika keadaan tersebut berlangsung lama maka akan terjadi gangguan fungsi ginjal berat yaitu terjadinya perubahan struktur ginjal berupa nekrosis di tubulus atau korteks. ${ }^{13}$

Penggunaan obat gentamisin bukan merupakan faktor risiko terhadap terjadinya gagal ginjal akut pada penelitian ini. Hal ini sesuai dengan penelitian Olavarraa dkk dan Robert dkk. ${ }^{15,16}$ Akan tetapi beberapa penelitian seperti pada Gupta $\mathrm{dkk}^{9}$ dan Aggarwal $\mathrm{dkk}^{17}$ telah melakukan eksklusi terhadap bayi yang mendapat pengobatan antibiotik golongan aminoglikosida termasuk gentamisin sehingga meminimalkan adanya faktor perancu akibat pemakaian obat nefrotoksik. Hal tersebut sulit dilakukan pada penelitian ini karena pemakaian obat gentamisin merupakan bagian dari prosedur tetap pengelolaan bayi yang lahir dalam keadaan asfiksia dan dicurigai mengalami infeksi neonatorum.
Beberapa penelitian yang telah dilakukan didapatkan bahwa gentamisin memang mempunyai potensi nefrotoksik akan tetapi potensinya bergantung pada dosis dan durasi pemberian. Pemakaian pada dosis tinggi atau pemakaian yang melebihi durasi 14 hari mempunyai risiko lebih besar terjadinya nefrotoksisitas dikarenakan disfungsi dari lisosom tubulus proksimal. Akan tetapi kelainan ini bersifat reversibel jika pemberian obat dihentikan, sehingga pemakaian gentamisin pada neonatus masih dipakai sampai saat ini. ${ }^{14}$ Penelitian kami menunjukkan bahwa pemakaian gentamisin masih dalam rentang dosis $(5 \mathrm{mg} / \mathrm{kgBB} /$ hari dalam dua dosis) dan durasi yang dianjurkan.

Keterbatasan penelitian ini adalah dalam hal penegakkan diagnosis asfiksia masih belum menggunakan kriteria WHO terbaru yang antara lain menyebutkan adanya gangguan syaraf pusat yaitu HIE dikarenakan munculnya HIE tidak dalam jangka pendek sehingga akan mengakibatkan kesulitan dalam melakukan inklusi sampel penelitian. ${ }^{18}$

Keterbatasan lainnya dalam hal pengambilan sampel analisa gas darah beberapa sampel didapatkan kadang bisa terkontaminasi dengan udara luar saat melakukan aspirasi dari pembuluh darah arteri, sehingga mempengaruhi kadar $\mathrm{PO}_{2}$ analisa gas darah.

\section{Kesimpulan}

Asfiksia berat merupakan faktor risiko terjadinya gagal ginjal akut. Disarankan untuk mengetahui adanya kejadian gagal ginjal akut maka neonatus dengan asfiksia berat hendaknya dilakukan pemeriksaan ureum dan kreatinin secara rutin pada hari keempat dan kelima. Perlu dilakukan penelitian selanjutnya yaitu berupa pemantauan jangka panjang fungsi ginjal bayi yang lahir dalam keadaan asfiksia berat.

\section{Daftar pustaka}

1. Dharmasetiawani N. Asfiksia dan resusitasi bayi baru lahir. Dalam: Kosim MS, Yunanto A, Dewi R, Sarosa GI, Usman A, editor. Buku ajar neonatologi. Edisi pertama. Jakarta: IDAI; 2008.h.103-25.

2. Rekapitulasi angka kelahiran bayi di RSUP dr. Kariadi Semarang tahun 2007. Data catatan medik. Semarang: RSUP dr. Kariadi; 2007. 
3. Mohan PV. Renal insult in asphyxia neonatorum. Indian Ped 2000; 37: 1102-6.

4. Fitzpatrick MM, Kerr SJ, Bradburry MG. Acute renal failure. Dalam: Postlethwaite RJ, penyunting. Clinical Paediatric Nephrology. Edisi ke-3. Oxford: ButtenvorthHeinemann; 2003.h.405-9.

5. Bergstein JM. Introduction to glomerular disease; anatomy of the glomerulus. Dalam: Behrman RF, Kliegman RM, Jenson HB, penyunting. Nelson Textbook of Pediatrics. Edisi ke-18. Philadelphia: WB Saunders Co; 2004.h.1573-6.

6. Hogg RJ. Acute renal failure. Dalam: Levin DL, Mons FC, Moore GC, penyunting. A Practical Guide to Pediatric Intensive Care. St. Louis: Mosby; 2004.h. 101-9.

7. Proesmans W. Acute renal failure in childhood. EDTNA ERCA. 2002; Suppl 2: 26-9.

8. Friedlich PS, Evans JR, Tulassay T, Seri I. Acute and chronic renal failure. Dalam: Teusch HW, Ballard RA, Gleason CA, penyunting. Schaffer \& Avery's diseases of the newborn. Edisi ke-8. New York: Elsevier, Saunders; 2005.h. 1298-306.

9. Gupta BD, Sharma P, Bagla J, Parakh M, Soni JP. Renal failure in asphyxiated neonates. Indian Ped 2005;42:928-34.

10. Karlowicz MG, Adelman RD. Nonoliguric and oliguric acute renal failure in asphyxiated term neonates. Pediatr Nephrol 2005; 9:718-22.
11. Hankins GD, Koen S, Gei AF, Lopez SM, Van Hook JW, Anderson GD. Neonatal organ system injury in acute birth asphyxia sufficient to result in neonatal encephalopathy. Obstet Gynecol 2002;99:688-91.

12. Andreoli SA. Acute kidney injury in children. Pediatr Nephrol 2009; 24: 253-63

13. Umboh A. Hubungan asfiksia neonatorum dengan gangguan fungsi ginjal pada bayi baru lahir. Sari Pediatri 2002;4:50-3.

14. Mortazavi F, Sakha SH, Nejati N. Acute kidney failure in neonatal period. Iranian Journal of Kidney Disease 2009;3:136-40.

15. Roberts DS, Haycock GB, Dalton R, Turner C, Tomlinson P, Stimmler L, dkk. Prediction of acute renal failure after birth asphyxia. Arch Dis Child 1990; 65: 1021-8.

16. Olavarraa F, Krause S, Barranco L. Renal function in full term newborns following neonatal asphyxia. Clinical Pediatrics 1987;26:334-8.

17. Aggarwal A, Kumar P, Chowdary G. Evaluation of renal functions in asphyxiated newborns. Trop Ped 2005;51:295-9.

18. World Health Organization. Basic Newborn Resuscitation: A Practical Guide. Geneva, Switzerland: World Health Organization; 2008. Diunduh dari: www.who.int/ reproductive-health/publications/newborn_resus_citation/index. html, pada 8 Maret 2011. 